\title{
Identity Drift: The Multivocality of Ethical Identity in Islamic Financial Institution
}

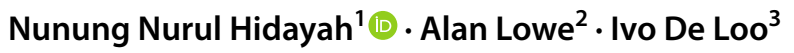

Received: 29 November 2018 / Accepted: 28 January 2020 / Published online: 6 February 2020

(c) The Author(s) 2020

\begin{abstract}
In today's neo-liberalist world, Islamic financial institutions (IFIs) face many difficulties combining contemporary financial thinking with Islamic, faith-based principles, on which their day-to-day operations ought to be based. Hence, IFI are likely to experience shifts/changes in organizational and ethical identity due to tensions that the combination of these principles invokes. We present an in-depth case study that focuses on these shifts in a major European based IFI across a 14-year period. We conceptualize identity change as drift, highlighting the multivocal nature of identity construction. The ethico-faith principles that were meant to serve as living codes of ethics guiding the IFI's organizational culture, operational processes, and strategy formation turned out to mainly have been discursively rationalized to respond to regulatory, market and institutional imperatives. The company is aware that it needs to engage in a continuous dialogue with those who set these requirements. Its ethico-faith principles may consequently be adapted quite radically, especially in periods of turmoil and takeover, as we show across the analysed time period. The paper provides valuable insights for faith-inspired organizations to reflect on the extent to which they wish to engage in the discursive justification and legitimization of current market hegemonies, whilst they actively encourage their managers to behave ethically as well.
\end{abstract}

Keywords Multivocality $\cdot$ Ethical identity $\cdot$ Organizational identity drift

\section{Introduction}

Islamic financial institutions (IFIs) are widely seen as aspiring to provide faith-based financial products and services to their clients that avoid interest (usury or riba) related transactions and other activities that are deemed to be exploitative and speculative (Iqbal and Mirakhor 2007; Warde 2010). It is assumed that, by taking this approach, ethically viable and acceptable transactions will result. However, it has been

Nunung Nurul Hidayah

N.N.Hidayah@soton.ac.uk

Alan Lowe

alan.lowe@rmit.edu.au

Ivo De Loo

i.de-loo@aston.ac.uk

1 Accounting Department - Southampton Business School, University of Southampton, Southampton, UK

2 School of Accounting, RMIT University, Melbourne, Australia

3 Accounting Department - Aston Business School, Aston University, Birmingham, UK noted that making ethically viable transactions may face IFI with difficult economic decisions due to the fundamental clash between the ontotheology of IFI and the epistemology of conventional financial institutions (Maurer 2001).

Competitive market pressures to conform to neo-liberalist principles may lead to the development and approval of products that would be deemed unethical from an Islamic perspective (Akhtar et al. 2008; Fang 2014; Warde 2010). In this context it may be difficult for IFI to provide financial services that fully preserve their faith-based ethical credentials (Fang 2014; Hidayah et al. 2018; Maurer 2012; Pitluck 2012). Maurer (2012) argues that IFI may consequently engage in a variety of interpretative and political practices that enable them to operate in a world where neo-liberalism and market logics dominate. Thereby, they may 'transcend' their purely ethico-faith identity and (claim to) effectively engage in a neo-liberally dominant financial 'world' without sacrificing their basic principles too much (Hegazy 2006; Pollard and Samers 2013).

This paper focuses on the context and day-to-day operations of such interpretive and political practices. It seeks to understand how organizations try to accommodate the 
socio-economic factors affecting (the portrayal of) their ethicofaith identities, whilst sticking to the principles underlying identities as much as possible. This will likely cause tensions, as the institutions have to entertain these neo-liberalist principles and may feel pressurized to introduce modified business practices. We seek to identify these tensions.

Our analysis in based on a process perspective of organizational identity (Alvesson and Robertson 2016). This perspective challenges the notions of centrality and distinctiveness that lead to reification or the belief in the "thing-like" nature of organizational identity (Corley 2004; Gioia et al. 2013). In further exploring a process perspective of organizational identity, we base our analysis on the concept of drift (Alvesson and Robertson 2016; Ciborra 2000; Gherardi 2006; Quattrone and Hopper 2001), which regards processes underlying both organizational and ethical identity constructions as being incomplete by default (Beech 2008; Sveningsson and Alvesson 2003).

Furthermore, we contribute to emerging discussions on ethical identity (Balmer et al. 2007; Koning and Waistell 2012; Verbos et al. 2007) by arguing that drift occurs as organizations embrace the multivocal nature of the processes that guide identity constructions. Our case organization shows the ability to tune in to the voices of various actors/institutions. The forces and feedback from wider participants induce self-reinforcing actions that play in the ongoing re(construction) of the organization's ethical identity. This paper also provides valuable insights for IFI and other faith-inspired organizations to reflect on the discursive positioning (Antaki et al. 1996) of their institution, and the extent to which they wish to engage in the justification and legitimization of the currently dominant way of rationalizing market hegemonies in particular, as they actively encourage their businesses and business managers to behave ethically, in line with Islamic faith-based principles.

The remainder of the paper is structured as follows. First, we explore the literature on organizational and ethical identity, which evolves into a discussion about drift. Drift is conceptualized as a process of identity becoming. Secondly, we outline the context, method, our approach to data collection and the approach we take in our analysis. In the sections thereafter, we explore three evolutionary processes of drift that we identify in our case context to translate/modify a particular IFI's ethico-faith identity given certain external influences it is faced with. We complete the paper by providing some conceptual and practical insights.

\section{Ethical Identity}

Studies of organizations frequently define identity as a set of subjective meanings and experiences collected by organizational members that help to address questions related to the core features of an organization, its self-image, or its distinctive character (Alvesson and Robertson 2016; Whetten 2006). Concerns over identity arise as organizations seek to distinguish themselves from other, similar organizations (Alvesson et al. 2008; Brown 2018). The existence of organizational identity is assumed to allow organizational members to describe what is central, distinctive, and enduring about their organization and how these characteristics act as a perceptual screen or filter that influences the way organizations process and interpret information (Dutton et al. 1994; Gioia and Thomas 1996).

Organizations claim an identity to define what the organization stands for (Alvesson et al. 2008; Ravasi and Phillips 2011). That part of organizational identity that is constituted by the living codes of ethics that guide organizational culture, operational processes, strategy and leadership issues, such as ethical and social goals/missions, is sometimes referred to as an organization's ethical identity (Verbos et al. 2007). It has been argued that an organization's ethical beliefs and viewpoints (Berrone et al. 2007) are equally as important as their profit motives in shaping organizational life, especially in the case of Co-operative or Islamic banks (Balmer et al. 2007; Berrone et al. 2007; Haniffa and Hudaib 2007). An organization's ethical identity is often believed to be the result of an ethicalization process (Gray and Balmer 2001; Romani and Szkudlarek 2014). In this process, it is surmised that ethical beliefs/viewpoints prevailing in an organization can contradict with existing organizational prescriptions, which either requires a transformation or resolution (Voronov and Vince 2012) to create a new consciousness of organizational identity (Giorgi et al. 2014; Giorgi and Palmisano 2017). A mismatch might appear between the personal understandings of organizational members and the ethical ideals being promoted by an organization, or it may arise from members' encounters with stakeholders that challenge the understandings of the organization's ethical beliefs (Alvesson and Willmott 2002; Klein 2001).

These circumstances effectively shape ethical identity as temporary and context-sensitive, representing an evolving set of constructions associated with the dynamic character of the larger social 'world' or milieu (Alvesson et al. 2008). Ethical identities are ascribed as always in-progress and continually being appropriated and negotiated in response to changing external stimuli, circumstances and interests (Sillince and Brown 2009; Thornborrow and Brown 2009). In exploring changes in ethical identity, it is crucial to reflect on Alvesson and Robertson (2016) criticism on the way most of the associated literature (Corley and Gioia 2003; Gioia et al. 2000, 2013) has reified organizational identity. This literature has typically framed the organization as an individual who is or can be made aware of whom he/she is (is not) as compared to other organizations. The process of identity change might more appropriately be viewed as iterative and 
often unstable in response to multiple embedded, overlapping and interrelated discourses at both organizational and societal levels (Brown 2018), in which one particular 'voice' or discourse may suddenly or unexpectedly appear to be stronger or more prominent than other 'voices' or discourses, as discussed in the following conceptualization.

\section{Conceptualizing Drift in the Process of Becoming: The Multivocality of Ethical Identity}

An organization's ethical identity is not permanently static and cannot be separated from its environment (Gherardi 2006; Quattrone and Hopper 2001), as we discussed in the previous section. It is an ongoing accomplishment, or a process of becoming (Alvesson and Robertson 2016). The ethical identity of an organization is a somewhat messy collage that results from negotiations, deals, improvisations and layers of appropriations that respond to the sheer complexity of organizational life (Ciborra 2000). An organization's ethical stance does not operate as a linear progression from a fixed and clearly identifiable point A (an organization's former or current state) to a fixed and equally identifiable point B (its current or desired future position). Organizations embrace multiple voices, forces and feedback mechanisms from multiple actors that create self-reinforcing actions at play in the construction, corroboration, and progression of ethical identity in everyday organizational life (Ciborra 2000). Hence, identity is always in flux.

In infusing and sustaining particular ethical viewpoints, organizations naturally engage in ethical identity drift, and slight (and not so slight) deviations from their planned purposes. Viewing organizational change as drift enables researchers to explore the unpredictability and consequently the uncontrollability of change. In the process of drift, organizations might experience gradual loss of clarity as they interact with various stakeholders (Balmer et al. 2007; Koning and Waistell 2012; Oliver et al. 2010). In the drift of ethical identity, organizations either have to engage in 'invisible mending' through which organizational identity is translated to restore and collectively enact the (seemingly existing) 'status quo', or by extending or adapting existing prescriptions of organizational practices through discursive, material, as well as emotional alignment (Gherardi 2006, p. 181).

Any drift entails a long, tortuous, and fragile process of alignment of various interests, powers and authorities that is never completely resolved (Ciborra 2000). In our case, drift represents an organization's ability to embrace different voices and develop a singular, multi-rationality ethical identity. The multivocality of ethical identity enables organizations, and organizational members in particular, to respond to struggles that automatically come with multiple and competing interests or sets of beliefs or knowledge of appropriate organizational practices under specific circumstances, in which it can never be said upfront which set of beliefs will come to dominate. Organizational change consequently can no longer be viewed as a transition from one state to another as judged from a single perspective/ rationality. Rather, it may be interpreted more appropriately as a process in which organizational practices construct and make sense of multiple knowledge, actions and rationalities to achieve a temporary, but incomplete resolution. Not everybody is likely to be fully satisfied with whatever is deemed to be the 'outcome' of these processes, given the diverse range of interests involved.

Studies in IFI practices reflect elements of the drift from the ideal equity-based transactions/products, which promote partnership and entrepreneurial activities, into debt-based transactions/products that are more acceptable to contemporary Western banking and financial markets (Diwany 2010; Fang 2014; Siddique and Iqbal 2017). An IFI's ethical identity can be seen as an evolutionary adaptation and ingenuous innovation to dominant social, market and legal institutional settings (Pitluck 2012; Vogel 2000). It may be argued that the drift of an IFI's ethical identity typically manifests itself in the shift from thick/normative to thin/procedural and legalistic conceptions and the fabrication of religious compliant financial instruments (Hegazy 2006; Pollard and Samers 2013). The legal policies/decisions (fatwa) associated with the ethical identity in IFI are repositioned or modified to cope with the extant logics and values of contemporary financial markets (Ullah et al. 2012). This drift can also be seen in the nature of IFI product development, which has determined the state of the art in global finance and Islamic financial products (Akhtar et al. 2008). The introduction of fixed returns on Islamic financial products (Hidayah et al. 2018) or the use of what is conceived as Islamic substitutes of conventional derivative products represent a move away from an earlier, ostensibly more authentic ethical identity (Maurer 2001; Rethel 2017).

Exploring the drift of ethical identity enables researchers to unveil the processes through which actors seek to balance multiple voices of different authorities that have various interests and order to deliver appropriate responses to their wider environment, from both inside and outside of an organization (Oliver et al. 2010). Ethical identity may be seen to be more socially connected, open and reflexive, as organizations construct more responsive types of organizational practices (Balmer et al. 2007). This conceptualization provides the main motivation for this research: how do organizations accommodate the socio-economic circumstances they are faced with, as well as the multiple, and perhaps partially overlapping interests and demands affecting the portrayal of) their ethical identity, whilst retaining the 
underlying, original Islamic principles associated with its ethico-faith identity?

\section{Research Context, Method and Design}

To address the research question, we investigate how a particular IFI, the Ethical Trust Bank (ETB), which is one of seven fully-fledged IFI operating in Europe, ${ }^{1}$ engaged in the adaptation or rationalization of specific ethico-faith principles within its contingent socio-economic and regulatory circumstances. The focal point of our research is the drift of these principles in incomplete attempts at organizing an ethico-faith based financial institution that fully adheres to its original Islamic outlook.

\section{Research Context}

ETB has operated for almost fourteen years in one of the leading European financial markets. Following its incorporation in 2004, ETB aspired to provide ethico-faith banking alternatives. ETB claimed that Islamic principles (Shariah) stressed the importance of honesty, transparency, accountability and ethics in structuring and executing its business and commercial affairs (Iqbal and Mirakhor 2007; Thomas et al. 2005; Warde 2010). For instance, the ethical principles of Shariah prohibit ETB from engaging in interest-based activities, the trading of forbidden objects (e.g. the breeding of pigs, sale and distribution of alcohol, and gambling businesses), accepting excessive uncertainty, and taking gain without either exerting effort or accepting liability (Khir et al. 2008). ETB was expected by its stakeholders to deliver ethico-faith-based financial products dedicated to empowering society through partnership and philanthropic activities.

In practice, the ethico-faith perspective of finance described above often turns out to contradict the logics of modern, neo-liberalist banking practices. ETB had no other option but to translate the ethico-faith principles it adhered to meet the internal and external demands it faced. We assert that ETB has modified its ethico-faith vision in three distinct episodes of change whilst trying to maintain the ethico-faith commitment of its business practices. ETB's ethico-faith principles have been represented in its value statements and Articles of Associations, which have clearly changed over time as a result of the company's desire and regulators' demands to meet regulatory requirements, as well as through

\footnotetext{
1 There are currently five fully-fledged IFI operating in the UK, Germany, Denmark and Bosnia. This study obscures the identity of the case organization and the specific country where it operates, due to the confidentiality agreement that was signed with its representatives.
}

ETB's response to market and shareholder demands as it went through several company takeovers.

The first episode of ETB's ethical identity change took place in the early stage of ETB's life, and essentially between 2004 and 2006. ETB had to get established as a serious bank in a country known as one of the main financial hubs in Europe. ETB had to modify its ethico-faith references to incorporate the 'voice' of the banking regulator of that particular country. The ethico-faith references in ETB's initial Article of Association had to be appropriated to follow regulatory prescriptions, as we will analyse below.

The second episode of change took place between 2006 to the end of 2013. The pressures from market competition to offer different services, and offer existing services differently, together with increasing financial losses had a substantial impact on ETB's performance until 2009. From the third quarter of 2009 onward, ETB decided to engage in reverse engineering practices of its financial products, thereby effectively replicating the structure and effect of particular, conventional banking products. ETB also sold its majority ownership in 2010, which brought in additional capital to sustain its operations. The company's new management, from 2010 to 2013, supported the idea of responding to market pressures by changing its approach to product development and accommodated its then current ethico-faith commitment to follow the market practices.

In the third episode, further changes of ETB's ethico-faith orientation can be witnessed. This happened in particular in the period between 2014 and 2018, when ETB tried to fulfil shareholder ambitions to a greater extent than before. In 2013-2014, ETB suffered from further liquidity problems that required another sale of company ownership to a foreign investment company. This company took over ETB's ownership in 2014 as part of the strategy to scale up its business in the European market. It bought ETB's majority ownership for $£ 76$ million. The new owner explicitly stated his ambition to become the leader of Islamic banking products and services in this particular hub of the European financial market. First of all, it was decided to change ETB's name into 'NewETB' to freshen up its identity, and the way it was seen on the market. In addition, NewETB's CEO and managing director adopted a totally different business approach than the previous CEOs and managing directors, which allowed them to leverage the ethico-faith label (which the rebranded bank still says it adheres to) further and engage in more practices commonly adopted by conventional banks. NewETB now focuses strongly on products and returns that have a similar structure and nature to its competitors, which do not necessarily follow Islamic, faith-based principles in their operations. Focusing on premium investors and highly leveraged financing or syndication deals has allowed NewETB to strengthen its performance markedly. 


\section{Method}

This study contains a qualitative case study, involving interviews and observations on the case organization's operations, which is supported by an extensive analysis on the company documentations across a 14 year period. We seek to examine the way ETB has tried to transcend various socio-economic contingent event, issues and circumstances affecting its ethical identity construction over the years, albeit with mixed results. We explore how ETB embraced multiple rationalities and praxis by aligning multiple actors' voices in spatiotemporal sequences of ethical identity drift (Alvesson and Robertson 2016; Ciborra 2000; Gherardi 2006; Quattrone and Hopper 2001). Through the case study we try to understand how processes of drift in ethical principles took form as indigenous organizational beliefs/interests and exogenous forces associated with the market and regulatory structures interacted across three time periods.

\section{Data Collection}

We collected our data across 6 months at ETB's main site, where we were able to conduct observations and interviews around ETB's daily operations, and were allowed to view company documentation that we deemed relevant to changes in ETB's ethical identity. In total, we conducted 30 interviews with ETB's managers/staff and external stakeholders, including 6 influential individuals in the national banking and financial regulatory institutions and 3 international regulators. We also interviewed a Shariah Officer who had previously worked for ETB, a number of ethical advisors, customers and other community members, as shown in Table 1 . During the period of case study, we participated in a two-day session, in which community members and several scholars discussed how they felt about ETB's past and current operations. We also observed several discussions between ETB and the global banking industry representatives at annual conferences/ workshops that took place in the 2013-2018 period.

The data from the interviews and observations have been triangulated with internal documentation and external regulatory reports and other relevant information dating from the 2004 to 2018 period. Those documents and reports, as listed in Table 2, have been especially insightful for examining the way ETB embraced and dealt with the (occasionally changing) 'voice' of shareholders, regulators, the banking industry and market participants that affected its ethical identity (construction).

We have reconstructed, in as much detail as space allows, the drift of ETB's ethical identity across three
Table 1 Research participants

\begin{tabular}{|c|c|c|c|}
\hline $\begin{array}{l}\text { Research partici- } \\
\text { pants }\end{array}$ & ЕTB & $\begin{array}{l}\text { External partici- } \\
\text { pants }\end{array}$ & Total \\
\hline \multirow[t]{3}{*}{ Regulator } & & Local: 6 & \\
\hline & & International: 3 & \\
\hline & & Total: 9 & 9 \\
\hline \multirow[t]{5}{*}{ Manager/Officer } & Manager/Officer: 9 & $\begin{array}{l}\text { Previous Man- } \\
\text { ager: } 1\end{array}$ & \\
\hline & $\begin{array}{l}\text { Managing Direc- } \\
\text { tor: } 1\end{array}$ & & \\
\hline & Shariah Officer: 1 & Ethical Advisor: 2 & \\
\hline & SSC Member: 2 & & \\
\hline & Total: 13 & Total: 3 & 16 \\
\hline \multirow[t]{4}{*}{ Community } & & Bankers: 2 & \\
\hline & & Customer: 2 & \\
\hline & & $\begin{array}{l}\text { Religious Scholar: } \\
1\end{array}$ & \\
\hline & & Total: 5 & 5 \\
\hline Total interviewees & & & 30 \\
\hline
\end{tabular}

different stages of the company's life, from its inception in 2004 through to the first quarter of 2018. Data have been supplemented by publicly available information about ETB/NewETB value commitment, market developments as well as broader socio-economic developments that have affected the ethical identity during the 14 years period.

\section{Data Analysis}

The interviews were typically transcribed and analysed using NVivo 9.2 qualitative data analysis software. We were requested not to record our two interviews with an internal audit manager and a treasury officer. Notes were taken in these cases, which were shown to the interviewees for comments and approval. We assembled our data across the three time episodes that have been mentioned earlier and categorized them based on changes in identity resulting from tensions between Islamic and neo-liberalist financial principles, taking into account the discursive positioning of our interviewees (Antaki et al. 1996; Klitsie et al. 2018), negotiations and dialogic constructions that could be singled out (Beech 2008; Sveningsson and Alvesson 2003). We developed themes that were prevalent and recurrent in each of the three episodes, in order to understand what had happened. We identified the internal and external contingent factors, that we believed enabled these processes of ethical identity drift. We found multiple instances in which ETB (re)constructed its ethical identity in order to respond to regulatory and market pressures, as well as to shareholder ambitions. Our analysis suggested the drift of ethical identity occurred in an evolutionary process, as ETB embraced the internal 
Table 2 Documents observed and analysed

\begin{tabular}{llc}
\hline Level & Type of documents & $\begin{array}{c}\text { Documents } \\
\text { availability }\end{array}$ \\
\hline Regulator & Policy Prospectus & 1 \\
& Discussion Paper & 1 \\
& Muslim Council Report & 1 \\
Bank/institution & Article of Association & 4 \\
& SSC Pronouncements & 3 \\
& Procedural Documents & 18 \\
& Shariah Review & 8 \\
& Shariah Audit Report & 14 \\
& SSC Products/Services Certificates/Approvals & 18 \\
& External Report & 29 \\
National/international guid- & Guidance from the Muslim Council & 519 \\
ance & International Shariah Standard & 1 \\
& International Shariah Audit guidelines & 1 \\
& & 1 \\
\hline
\end{tabular}

and external voices that challenged the re(construction) of the organization ethical values.

\section{Findings: Episodes of Drift and Multivocality Surrounding ETB's Ethico-faith Identity}

In this section, we begin our discussion with the ethical vision that was espoused at the inception of ETB's operations in 2004. Following its incorporation in 2004, ETB focused on fulfilling an aspiration to provide ethico-faith banking alternatives. At the time, ETB publicly stated that ethico-faith values underpinned all of its operations, as highlighted in the following vision and values statement:

Our aim is to provide banking services to the community at large. We aim to adhere strictly to Shariah, as set down in Islamic teaching. All our products and services are Shariah compliant as approved by our Shariah Supervisory Committee. These services are founded on the values established within the Islamic faith....Our values come from the values established within the Islamic faith, and these values we believe to be essential to any well-run, independent bank. (ETB's Vision and Values - 2004)

In both formal and informal media communications ETB addressed its vision based on the common Islamic tenets that it had to offer appropriate ethical and religious based financial alternatives. The commitment to follow Islamic principles of Shariah was also included in ETB's initial Articles of Association, as shown below.

It is intended that the business affairs of the Company shall be conducted in accordance with Shariah. Activi- ties of the Company will at all times be supervised by the Shariah Supervisory committee. The Directors of the Company are obliged to ensure that the business of the Company is at all times Shariah compliant. (ETB's Article of Association - 2004)

ETB further indicated that its products and services would be positioned to serve Muslim society by providing financial alternatives based on a 'transcendental' Islamic frame of reference. It sought to promote equity finance by offering profit and risk sharing instruments that aimed to support the growth of small businesses and entrepreneurs. ETB's ethical ideals strongly suggested the importance of providing noninterest-based instruments that protected all parties from excessive uncertainty and speculative activity. ETB also claimed a clear religious commitment, stating that all of its transactions should be in line with the principles of Shariah that is overseen by a distinct religious governance structure.

The SSC is comprised of experts in the interpretation of Islamic law and its application within modern day Islamic financial institutions. They are world-leading scholars representing a wide spectrum of the Islamic faith. The SSC should ensure that Shariah compliance is at the heart of everything ETB does and every product and service that it offers. (ETB Media reporting)

A team of in-house religious scholars, known as the 'Shariah Supervisory Committee' (SSC), differentiate ETB from the Western banks by monitoring the implementation of ethico-faith principles. The SSC is an independent body akin to an audit committee in a conventional organization, providing Shariah assurance on all banking and financial activities. The SSC was established two years 
prior to ETB, gaining a licence as an IFI and commencing business. Shariah assurance work typically starts at the time an institution is conceived. The SSC is involved in drafting the company's Article(s) of Association, business plans, and product offerings, to ensure the (correct and adequate) inclusion of religious compliance principles. The development of retail banking products, such as current and deposit accounts, home finance, and personal finance products must be approved by the SSC. Shariah compliance aspects of every product are certified by the SSC, by issuing a legal opinion (fatwa). They also issue Shariah compliance certificates on ETB's products. An excerpt from one of the certified product certificates is as follows:

In compliance with the Terms of Reference of the Committee, having reviewed the Master Murabahah Agreement documentation including all related contracts, literature and all associated processes, and after making all required amendments, we the 'Shariah Supervisory Committee' for Trust Ethical Bank confirm that in our opinion the Master Murabahah Agreement is in accordance with the Murabahah principles in Islamic finance and therefore we allow the bank to provide this facility to its customers. (Shariah compliance certificate - Master Murabahah agreement)

An internal Shariah Compliance Officer (SCO) is responsible for supporting the SSC to undertake regular Shariah assurance and an annual Shariah audit, to ensure ethicofaith principles are sufficiently adhered to in practice. The detailed results from these Shariah assurance processes complement ETB's other reports to its stakeholders. Those Shariah assurance processes, however, cannot prevent the repeated attempts at organizing ETB's ethico-faith identity in the face of various socio-economic pressures, as exemplified in Fig. 1.

Taking cues from Fig. 1, we will elaborate on the three periods of drift, and the issues associated and impacting on these, in the following sub-sections.

\section{First Episode (2004-2006): Modifying ETB's Ethical Identity to Suit Regulatory Requirements}

In this section, we explore the first drift of ETB's ethical identity. In its early years of operation, the main challenge ETB faced was to integrate the aspired ethico-faith vision as explicated in its Article of Association with existing regulatory imperatives. The ethico-faith aspiration, however, largely proved foreign to a Western banking industry culture and regulatory environment. The growing interest of Muslim investors in financial alternatives that are in line with religious belief is seen as an opportunity in the Western market.
Islamic finance is a fast-growing force in the world economy, we take an open and principle-based approach to regulation. We offer the right environment for it to flourish in our country. There is huge potential for an expansion of Islamic offerings in the European financial markets, which will in turn boost our country's position as an international financial centre. (Chairman of the Financial Authority)

Financial authorities, as expressed above, see Islamic banking as an avenue to expand the existing market. Embracing Islamic finance is also a way to strengthen the country's position as the hub of the European market that may further capture global investors. The extract below makes very clear that the government view is to not include any faith-based elements or Shariah principles in the existing regulatory framework.

... The Government does not intend to adopt a stateled approach to improving standardisation in Islamic finance. The Government believes that such an approach would not be appropriate ... the financial authorities are secular bodies, not religious regulators. (Government Report on Islamic Finance, 2008)

The opportunity provided for Islamic finance, was not to affect the nature of regulatory policies imposed on any financial companies operating in the country. Islamic finance would be encouraged by adopting a 'no obstacles' approach but the regulatory regime would not be adjusted in any way to reflect Islamic Law requirements in order to maintain the 'no special favours' in the financial market:

It is essential we seek out new opportunities to diversify our financial services industry, so the industry can continue to prosper and grow. We believe in a 'no obstacles, no special favours' approach when authorizing Islamic financial institutions and welcome the development of this market as it provides certain consumers with financial products that are in line with their beliefs. Providers of ethical/faith-based finance have the potential to position themselves as a viable alternative to mainstream institutions... (Central Banking Authority)

There clearly was no space for a variation in regulations to address, for example, the uniqueness of Islamic finance contracts. Regulators have remained reluctant to address religious compliance in their standards and guidelines ever since ETB's inception, as shown in the following narrative.

We had no objection in principle to the idea of Islamic banks ... provided Islamic banks met the regulatory requirements. We had a clear economic interest in trying to ensure that the conditions for a flourishing Islamic market are in place in our 
Fig. 1 Episodes of ethico-faith identity drift at ETB

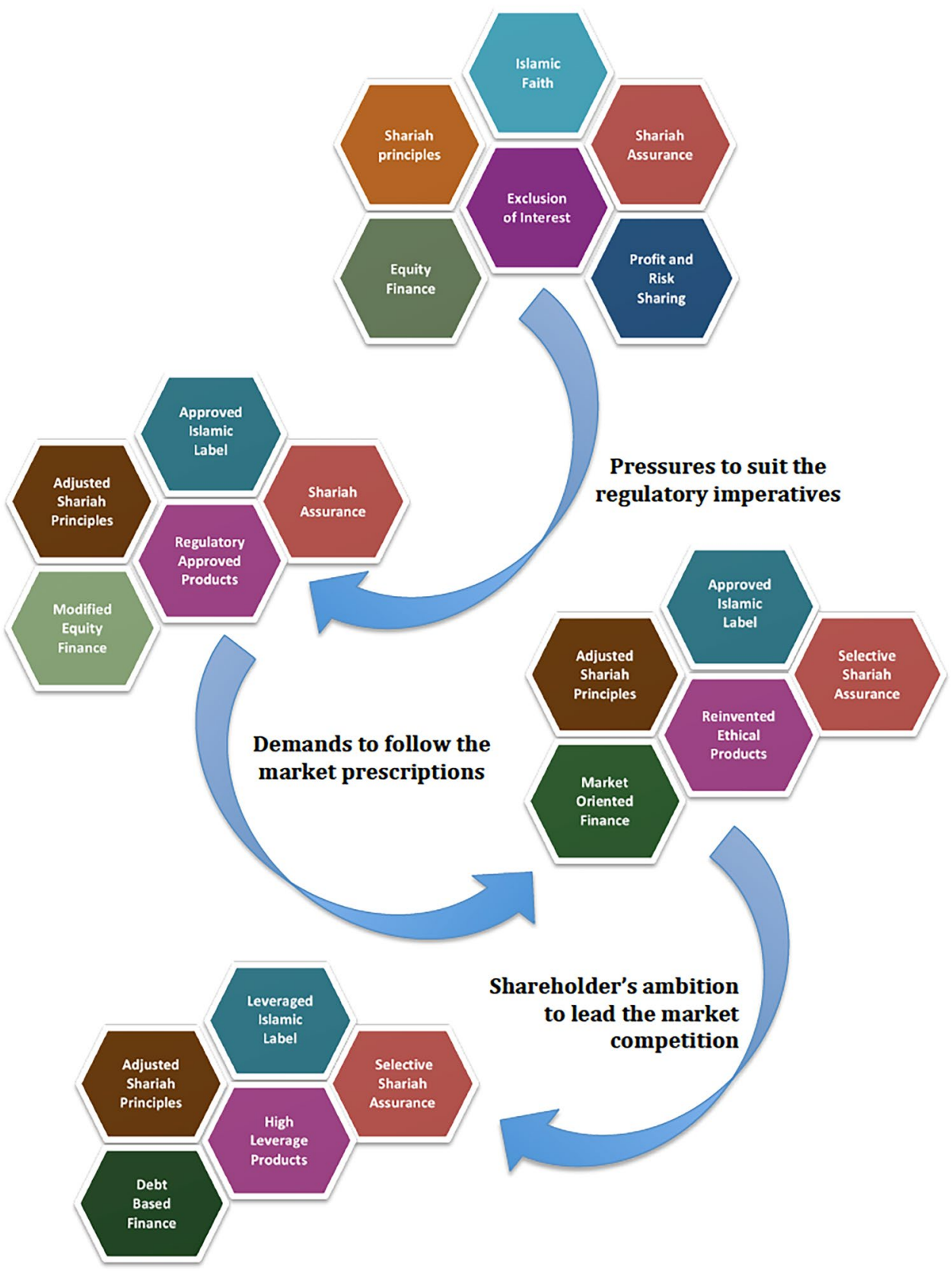

country. A soundly financed and prudently managed Islamic institution would be good for Muslim consumers, good for innovation and diversity in our markets as an international financial centre. (Financial Authority Officer)

The coherence of the existing regulations is preserved. The regulators equally imposed the same level of regulations that governed all banking and financial operations in the country. ETB consequently had no choice but to follow the regulatory imperative. ETB has to comply to the local banking regulations and prudential regulatory framework, as narrated below.
Islamic finance products in this country are not regulated any differently from conventional instruments and existing legislation and regulations apply. Our approach has been to ensure a level playing field for Islamic finance products and conventional instruments, and so we have proactively monitored and responded to any unequal treatment between the two by introducing remedial legislation and regulations. (The Government Islamic Finance Specialist)

The financial authority has been, and is, willing to play its part in supporting these developments, within its regulatory powers. Although we cannot promote Islamic finance (or any other particular kind of finance) 
we can give a clear regulatory framework, which is flexible enough to adapt to changes in the market... (Financial Authority Report, 2007)

The regulator places a strong emphasis on ensuring a level of playing field for all financial institutions. ETB has to ensure that any products are both meeting Shariah principles and regulatory requirements. Any clashes between these requirements are discussed and negotiated to satisfy the regulators, as expressed below.

It is impossible to apply faith-based ethical principles within the financial services sector without plenty of discussion... it is important to bring together practitioners and stakeholders with a very wide range of perspectives. (The Government Ethical Finance Advisory Member)

At times, ETB has to adjust the nature of its original Islamic contracts or legal requirements in order to comply to the banking regulations. The liquid asset buffer rules for example, requires financial institutions to obtain a liquid assets buffer to protect customer investments by using high debt securities, reserves in the form of sight deposits in the central bank, or investments in designated money market funds. Such interest-based transactions, however, breach the basic tenet of Shariah principles. The ETB SSC has argued that interest-based liquidity instruments should be avoided. This example represents one of the tensions ETB faces between regulatory requirements and Shariah principles, as indicated below:

We have had some discussion with the financial authority around the liquid asset buffer requirement because there are few Shariah compliant assets that conform to the regulatory requirements for the definition of the liquid asset buffer. There are some that are available, but [they are] not $100 \%$ appropriate for us. (Compliance Manager)

Other regulatory requirements, as shown in the extract below, also impinged on ETB's operations. This happened because the regulator wanted to prevent 'unforeseen consequences' resulting from the implementation of Islamic laws (Birchall 2013; Kurti 2013).

What we do not want is a situation where firms undertake arbitrage because one form of regulatory treatment offers favours over another. There is, therefore, a level playing field...it would not be appropriate, nor would it be legally possible, to vary its standards for one particular type of institution... (Financial Authority Officer).

Hence, there are clear occasions where the legal aspects of Islamic financial transactions are not in line with accepted regulatory rules. ETB in respond to that has to withdraw the offering of the original Islamic contracts (the profit and loss sharing schemes) that represent its identity as the legal elements would contradict existing banking regulations. The investment risks that customers bear in such contracts contradict the required investment guarantee regulatory requirements (Birchall 2013; Kurti 2013). This regulatory constraint triggered the shifting of ETB's products from providing profit and risk sharing instruments to other products common in the banking sector in the country of its operations.

The regulatory approach is to treat IFIs as it would conventional firms, so an IFI would require authorisation to carry on regulated activities and obtain the necessary permissions from the financial authority. IFIs may need to provide additional information in certain circumstances, such as the role, if any, that the IFI's Shariah board performs in relation to operational and financial matters... (Deputy Minister for the Government Strategic Policies)

To secure the regulatory approval, as expressed above, ETB had to negotiate with the financial authorities to balance the implementation of Shariah principles while meeting existing regulations. As a result, continuous discussions have been taking place between ETB and the regulator to achieve consensus on ETB's operational practices.

Certainly we'll leave it to the industry to establish policy practice ... We're trying to facilitate as much as possible while still maintaining a level playing field ... The government was quick to remedy the adverse tax treatment for Islamic finance products. The double stamp duty land tax charge on shariah-compliant mortgages, for example, were also abolished. But, we also want to ensure that IFI offers the product more widely, which would allow the Islamic bank to "future proof" the facility by ensuring there is adequate demand. (Financial Authority Officer).

The regulator, as seen above, argued that sufficient regulatory facilities had been allotted to ETB to operate on a European financial market. In order to resolve the tensions, ETB took an approach to reduce the practical complexities surrounding Islamic financial contracts. We are also able to trace those tensions in both internal and external documents that we analysed, as seen in Table 3 .

As seen in Table 3, there is pressure for ETB to revisit its value proposition to also consider its suitability within the existing regulatory imperative. Islamic financial schemes that clash with regulatory requirements are modified or even removed. The SSC Member and the Compliance Manager have to weigh both Islamic and banking regulations to 
Table 3 Documents observed and analysed during the first episode

\begin{tabular}{|c|c|c|}
\hline Tension in the first episode & Some of documents analysed & Main information discussed \\
\hline \multirow[t]{3}{*}{$\begin{array}{l}\text { Seeking approval for Shariah compliant bank- } \\
\text { ing }\end{array}$} & $\begin{array}{l}\text { Policy Prospectus, Article of Association, } \\
\text { Media Communications }\end{array}$ & Shariah principles as a basis for ETB operation \\
\hline & Discussion Paper & $\begin{array}{l}\text { Facility provided for Islamic finance with equal } \\
\text { regulatory treatment }\end{array}$ \\
\hline & $\begin{array}{l}\text { Muslim Council Report, Guidance from the } \\
\text { Muslim Council }\end{array}$ & $\begin{array}{l}\text { The effort in helping the government to under- } \\
\text { stand Islamic finance and how to remove } \\
\text { obstacles for ETB operation }\end{array}$ \\
\hline \multirow[t]{3}{*}{ Challenges due to equal regulatory treatment } & $\begin{array}{l}\text { SSC Products/Services Certificates/Approvals, } \\
\text { SSC Pronouncements }\end{array}$ & $\begin{array}{l}\text { Clashes between regulatory requirements and } \\
\text { Shariah principles, which includes guarantee } \\
\text { schemes, double taxation, etc }\end{array}$ \\
\hline & $\begin{array}{l}\text { Discussion Paper, SSC Pronouncements, } \\
\text { Procedural Documents }\end{array}$ & $\begin{array}{l}\text { Negotiation with the regulators and decision to } \\
\text { modify Shariah principles that contradict the } \\
\text { local rules and regulation }\end{array}$ \\
\hline & $\begin{array}{l}\text { Muslim Council Report, Guidance from the } \\
\text { Muslim Council, External Report, Media } \\
\text { Communications }\end{array}$ & $\begin{array}{l}\text { The Muslim Council discussion to provide } \\
\text { facilities/supports to achieve resolutions for } \\
\text { regulatory obstacles in ETB operation }\end{array}$ \\
\hline \multirow[t]{2}{*}{$\begin{array}{l}\text { Responses to overcome the regulatory chal- } \\
\text { lenges }\end{array}$} & $\begin{array}{l}\text { Article of Association, SSC Pronouncements, } \\
\text { Media Communications }\end{array}$ & $\begin{array}{l}\text { Modification of Shariah principles as the basis } \\
\text { of ETB operation by acknowledging the need } \\
\text { to comply to the local law and rules/regula- } \\
\text { tions }\end{array}$ \\
\hline & $\begin{array}{l}\text { SSC Products/Services Certificates/Approvals, } \\
\text { Procedural Documents }\end{array}$ & $\begin{array}{l}\text { Modification of the original contracts (profit } \\
\text { and loss sharing investment schemes) in order } \\
\text { to make it more acceptable/to achieve regula- } \\
\text { tory approval }\end{array}$ \\
\hline
\end{tabular}

achieve a negotiated version of the products at some point as expressed below.

Ehm... So we've been in fairly very lengthy discussions with them over that aspect of our business. The financial authority certainly understands some other complexities and challenges that Shariah finance presents in operating under this kind of conventional banking regulations. It is an ongoing dialogue... (Compliance Manager).

A problem would be if we couldn't solve this issue of the specificity of Islamic financial contracts. This should be developed and used in this [specific] way, so we should get some exemption, as long as the intention is to finance the client. If there is a proof that the intention is different, then let them [regulator officials] implement the acts/regulatory rules. This must be approached in a relaxed manner, so that a conventional bank and we can be treated on an equal footing ... As long as this is not really solved, no Islamic bank can work here. (SSC Member).

Both views above show that certain pressures and obstacles may influence the way ETB frames its ethical identity to offer Shariah compliant banking solutions. The identity attached to the original Islamic contracts/schemes cannot be implemented in pure form. Banking regulators play an influential role in shaping ETB's identity. Inevitably, the products that ETB offers to the market must meet the legal elements in place in order to secure regulatory approval, as discussed below.

The basic regulations for all banks also comprise the requirements for Islamic bank....it means they need to meet regulatory feasibilities, all banks have to do this.... (Shariah Compliance Officer).

As a consequence, regulatory pressures seem to have brought about the modification/adaptation of ETB's ethico-faith claims, as shown in the amended Article of Association dating from 2006:

The company is a Shariah compliant bank, which operates according to the Shariah guidelines. The Shariah will govern these articles as long as they do not conflict with the applicable laws of the land.

(Amended Article of Association - 2006).

ETB simply had no choice than to follow to the regulatory logic that dominated the financial industry at the time it was established. ETB's ethical identity, as exemplified by the aforementioned quote, came to represent a temporary convergence of conflicting references that shaped what constitutes ethical banking within the boundaries of religious and regulatory imperatives. This has been highlighted in the upper part of Fig. 1. 


\section{Second Episode (2006 to the End of 2013): Reverse Engineering of Islamic Financial Products to Meet Market Demands}

In this episode, we explore the drift of ETB's ethico-faith identity from 2006 to the end of 2013, as it faced the challenges of sustaining itself on the market given the increasing financial losses. The pressure to provide competitive products to a wider market segment subsequently increased. In this situation, engaging in the reverse engineering of Islamic financial products surprisingly came to be seen as a way to rectify the alleged lack of attention that had been devoted to securing high returns and capital growth of the business in its early life:

In the beginning, we weren't driven by the desire to make a return, and hadn't got the capital to make an impact, so it was all about passion. I was doing seminars in mosques and for business leaders, then we started building a branch network and I spent two years on the road. (Managing Director)

ETB, as a relatively new player on the financial market, struggled to compete with existing financial institutions that had a long history and established market positions, despite the efforts undertaken by, among others, its managing director to strengthen its identity. The size of the Muslim population, constituting ETB's primary potential market, continued to be relatively small, below $3 \%$ of the overall population in ETB's main market.

As an Islamic bank in a Western country, where Muslim are the minority ... you have to be able to tap into the wider market...Unfortunately, all the fixed overheads burned our cash. We strengthened the management team, and started pushing deposit accounts, but the fuel was still running out. (Managing Director).

ETB's marketing practices to attract potential customers of an aspired ethical identity were extensive and timeconsuming for a new organization in a relatively stable and well-developed market. ETB turned out to have insufficient capital to successfully establish itself on the market. Along with the stiff competition, these development processes placed enormous burdens on ETB's financial resources.

... being Shariah compliant isn't sufficient for customers to buy our products. We also have to be competitive. You know.... Once there were some customers who would come to us as a matter of choice because we were Shariah compliant-it was in line with their faith and ideology. However, not all Muslims will feel that way. They won't feel compelled to align themselves with a Shariah compliant alternative, if it does not provide them with competitive products... It has to be priced correctly. If it is a lot more expensive, and it doesn't give the return that they expect to have, Shariah compliance may not be enough for Muslims. (Senior Marketing Officer).

ETB tried hard to attract clients from across the community to increase the level of customer deposit by marketing the attractive ethical aspects of Islamic financial products. The Muslim community was the main targeted customer group, as ETB's products had primarily been designed to suit their ethico-faith based beliefs. Despite the attractiveness of the products it became clear customers also demanded competitive returns. The fees on such products, however, could not decrease below a certain threshold if ETB's operational costs were to be recovered. The inability to lower costs had a huge impact on ETB's financial performance.

The balance sheet isn't looking good. We don't have enough assets, simple as that. Hmm... we have not got critical mass in terms of retail assets. There are factors that kind of align to that. Hmm.... such as] the significant drop in base rates. You know the last two years now, hmm.... the earnings on treasury assets have been substantially reduced. Hmm.... which is impacted the ability to achieve profitability. .... Particularly where we were sitting on large amounts of essentially cash, short-term funds, short-term customers' funds that we couldn't then use to finance longer-term retail assets. The return on liquid assets was substantially reduced. (Manager of Finance).

The complex market challenges hurt the financial performance of ETB. During the period 2008-2010, for example, ETB suffered an average yearly loss of almost $£ 4$ million. The declining financial performance required ETB to revisit its product range. In the third quarter of 2009, ETB started to engage in the reverse engineering of its faith-based ethical/Islamic financial products, through which it sought to replicate the effect of conventional banking products, while trying to keep contractual frameworks in compliance with Shariah requirements, as seen in both internal and external documents that we analyse in Table 4.

As discussed in Table 4, the reverse engineering seemed to yield products that conformed to the legal form of Shariah, but these did not really fulfil the substance of its ethicofaith principles. Through these ingenious innovations of Shariah compliant products, ETB achieved the economic effects of the conventional products that contain ethically prohibited transactions. In order to support these innovations, the SSC supported the adjustment of Shariah principles governing ETB's products. The difficulty in implementing all principles of Shariah in the Islamic finance industry is acknowledge by the regulator, as discussed below. 
Table 4 Documents observed and analysed during the second episode

\begin{tabular}{|c|c|c|}
\hline Tension in the second episode & Some of documents analysed & Main information discussed \\
\hline \multirow[t]{3}{*}{$\begin{array}{l}\text { Financial challenges and difficulties in imple- } \\
\text { menting the Shariah contracts }\end{array}$} & External Report, Media Communications & $\begin{array}{l}\text { Financial issues, which includes high level of } \\
\text { costs and losses ETB face }\end{array}$ \\
\hline & External Report, Media Communications & $\begin{array}{l}\text { The need to be more competitive in the market } \\
\text { to sustain the business within the high com- } \\
\text { petition in the market }\end{array}$ \\
\hline & $\begin{array}{l}\text { Discussion Paper, SSC Pronouncements, Pro- } \\
\text { cedural Documents, SSC Products/Services } \\
\text { Certificates/Approvals }\end{array}$ & $\begin{array}{l}\text { Decision to focus on maintaining the business } \\
\text { by focusing on more attractive contracts for } \\
\text { both Muslim and Non-Muslim customers }\end{array}$ \\
\hline \multirow[t]{2}{*}{$\begin{array}{l}\text { Reverse engineering of Islamic financial } \\
\text { products }\end{array}$} & $\begin{array}{l}\text { SSC Pronouncements, Media Communica- } \\
\text { tions, SSC Products/Services Certificates/ } \\
\text { Approvals, Procedural Documents }\end{array}$ & $\begin{array}{l}\text { Development of hybrid products or combi- } \\
\text { nations of several Islamic contracts that } \\
\text { produce similar schemes/products to that of } \\
\text { the conventional competitor }\end{array}$ \\
\hline & $\begin{array}{l}\text { External Report, Media Communications, SSC } \\
\text { Pronouncements }\end{array}$ & $\begin{array}{l}\text { Justification of using conventional banking } \\
\text { product reference, or basis for target return, } \\
\text { or products charges, such as effective yield } \\
\text { or the market interest rate, etc }\end{array}$ \\
\hline
\end{tabular}

In Islamic finance there are impediments to achieve an ideal state. A number of aspects which makes it very difficult to say that the standard that we issued must be adopted or must be enforced. The difficulties are in relation to the capacity at the institutional level [IFI level] to adopt and enforce the Shariah standard. There are diversity of market and institutional developments, and many of them are not in the position to adopt the standard as effectively as we wish. (International Regulator for Prudential Practices of Islamic Finance Industry-Chairman).

The adjustment of Shariah principles to satisfy local regulatory requirements and business demands is considered acceptable. The regulator agrees that the ability of this new business to sustain itself in the banking industry in Europe is also essential. Those rationales underlie ETB's choice. It is difficult to move away from the market imperatives. For example, the Islamic/Shariah compliant mortgage range was expanded during the period of 2009 with a fixed charge (called 'rental' in ETB's terms) product. The fixed charge provided a similar outcome to interest charges commonly paid on conventional mortgages. Following the success of investment banks to attract Middle Eastern investors, ETB also introduced a fixed-term buy for home ownership. The latter product gained substantial interest among targeted foreign investors. ETB also engaged in further modifications of specific ethical principles requiring all financial transactions to be based on actual assets involving real transactions. In supporting the company's approach, Shariah assurance has been selectively appropriated, by accepting a different interpretation of what constitute noninterest-based transactions.

In 2010, given the losses it still suffered, ETB felt it had no other option than to sell $80 \%$ of its equity stake to a foreign IFI. This takeover resulted in a flow of $£ 20$ million additional capital that allowed ETB to sustain its operations. The new owner set out to leverage its established retail brand in the Islamic finance sector, and increase sales of key products acceptable for the wider market. In late 2010, ETB began to launch more modified products to better fit with the market appetite.

We have to recognize that the Islamic finance business is relatively small... All your business models must be built up around the resource constraints that you have but still deliver the high expectations of the market we serve... ETB, in the mid of the 2000s, was in a kind of struggle with the $£ 20$ million of capital [from the new shareholder as a result of the first corporate takeover]. It means you have to be very careful of what you deliver. You have to allocate the capital carefully, in terms of the products that you deploy... You always need to be able to do more with less continuously... (ETB's new CEO).

The regulators for the Islamic finance industry do not see this adjustment as an issue from a Shariah point of view, as suggested by the prudential regulator below. It is regarded as a necessity in order for ETB to maintain its performance in the Western market.

We need sequencing. We cannot do everything. We have to do everything, but we could ask what we need to do first? The regulators think the first thing is to issue the licence, but they have forgotten a couple of things. They forget that the bank needs liquidity management instruments. The regulator also needs to know what the Islamic bank is facing. So, I think sequencing is a very critical issue. (International Regulator 
for Prudential Practices of Islamic Finance Industry - Chairman).

The regulator above understands that ETB cannot achieve its ethical ideals as projected. The regulators try to take into account the different challenges ETB faces in the market. The regulator is in support to ETB's strategy in the reengineering of its products in order to offer competitive returns to customers. In addition to maintain liquidity, the regulator supports ETB's strategy to engage in reverse engineering of its Shariah compliant products. The reverse engineering, of Islamic financial products, produced instruments that showed only tenuous links to any real sale or asset-based transaction, as suggested in the following text:

Islamic consumer financing transactions represent an agreement whereby the company buys a commodity or goods and then sells it/them to the customer with an agreed profit mark-up with settlement of the sale price being deferred for an agreed period. The customer may subsequently sell the commodity purchased to generate cash. (ETB annual report - 2011)

The type of financing mentioned above represents a virtual sale and buy-back transaction, without any real exchange of assets, as the customer's and the bank's intentions are to receive and provide cash financing based on a deferred payment. Elements of the Muslim community and the local religious scholar criticized this transaction as a back door to interest (riba) - its structure had a clear resemblance to interest-based financing. This reverse engineered scheme is well known as a tawarruq (sale and buy-back) contract. The legal structure looks Shariah compliant, but in essence it may best be seen as camouflage for a lending transaction covered by a sales-based transaction. The OIC Fiqh Academy, a worldwide reference on Shariah rulings, considers the sales and buy-back (tawarruq) as a deception, to the extent it may comply with the letter of the law, but it does not really comply with the spirit of Shariah (Goud 2010):

ETB offers an Islamic banking solution that has to be competitive and at the same time be able to offer solutions for Muslims in the West. (Senior Treasury Manager)

Arguing the need to provide acceptable market solutions to meet specific market demands, ETB employed the engineered sales and buy-back (tawarruq) as a contract for personal financial products from 2010 onward. ETB also offers similar transaction structures in its commodity-trading (murabahah) products. This enabled the company to virtually buy commodities on the spot market, and sell them to a customer for the spot price plus a profit margin. Subsequently, ETB acts as the customer's agent to reverse the sale on the spot market. The SSC rectifies the permissibility of such contracts by taking into account the challenges faced in the regulatory environment by Islamic banks. This is how one of the members on the SSC framed this permissibility:

.... the consumer protection act and the sales protection act will be implemented if we do ordinary murabahah [sales-based transactions]. If we buy a car and sell it, if an accident happened and there's a fault in the car, the bank is responsible first, it is liable. Nobody wants to take such liability, it can be very dangerous financially. So for this reason, the bank only does tawarruq and commodity murabahah.... (Shariah Supervisory Committee Member 2)

There is almost no physical commodity exchanged in the trading of commodity murabahah products. There is no real economic result following from such transactions either, but a customer receives cash alongside a deferred liability to the bank. This deferred liability equals the cash received plus a pre-agreed, fixed rate of expected profit, which is a semantic symbol of profit to replace the interest element within the contract. The SSC is aware that these contracts create a similar structure to the competitors' interest-based financial products. However, they choose to selectively adapt their interpretation of Shariah rules in these contracts to suit the ETB's demand for a steady profit and risk avoidance behaviour. The revenue recognition of these products were based on the predominant Western discounted cash flow model. That model does not represent the Islamic tenets in avoiding interest however, as evidenced by the information below from ETB's annual report:

Income, on both Commodity Murabahah and Wakalah receivables, is recognized on an effective yield basis. The effective yield rate is the rate that exactly discounts the estimated future cash payments and receipts through the agreed payment term of the contract to the carrying amount of the receivable. The effective yield is established on initial recognition of the asset and is not revised subsequently. (Described in ETB annual reports from 2009 to 2013)

ETB uses BBR or LIBOR to price its products, as these are the most accurate, widely accepted and consistent benchmarks for financing. This allows ETB to meet the important Shariah criteria of avoiding uncertainty. If rental rates were to be used as a benchmark instead, there would be too much variation... which would not be practical. (SSC Member - minutes of a Q\&A session in Shariah Scholar Public Forum in 2010)

The rate or margin of the above product is also benchmarked against market interest rates. The SSC supported ETB's approach and argued that this would bring no harm to the ethicality of the actual contract, as interest benchmarks 
are commonly used on the market, hence avoiding excessive uncertainty. The SSC further argued that the use of interestbased benchmarks and reverse engineering products could be used for operational practicality and to embrace the market demands in order to have a stable financial outcome. The selective Shariah interpretations and guidance in particular enabled the further adjustment of ETB's ethical identity due to the need to accord ethico-faith principles and market imperatives.

\section{Third Episode (2014-2018): Corporate Investment Banking Meets Shareholder Demands}

In this section, we explore the third drift of ethico-faith identity as ETB went through the last change of ownership in 2014. Despite attaining the highest level of retail asset finance and deposit balances during its existence in 2012, ETB still found itself facing losses and also difficulties in competing with a number of Western financial institutions operating in the country in which it is located. Another takeover of ETB's majority ownership by a new shareholder in 2014 gave ETB an additional $£ 76$ million of capital to spend.

As we summarized in Table 5, both ETB's internal and external documents show that through acquisition the new shareholder has a strong ambition to expand their multinational business into the European market. ETB was subsequently rebranded as 'NewETB', with a determination to strengthen its market performance, as discussed below.

The acquisition of the former ETB is the gateway in expanding our existing business into the growing European market. We intend to build upon these excellent foundations, not only through the continued growth of Shariah compliant savings and home finance products to European retail customers, but also by significantly developing the Bank's commercial business activities...We look forward to supporting NewETB in its growth plans by strengthening its balance sheet and position in the market. (New major shareholder).

The new CEO launched a strategy to transition the bank's operations and place more emphasis on corporate banking and premier services for wealthy customers. NewETB retained its managing director after the second takeover, but the company began to actively promote a different perspective on ethico-faith principles in its operations. The new shareholder tended to retain the Islamic label but took a more permissive approach to the importance of the ethicofaith principles. NewETB subsequently moved to include the financing of commercial property as an important strategic priority.

... The owners want to make their bank into a global brand, and we will be the European footprints of that 
ambition. Our name will change at the end of 2014 from ETB to NewETB. We will always be an IFI for retail customers. However, we will become more of a commercial bank, so there will be a greater focus on corporate and real estate finance. (Managing Director)

The bank launched a dedicated branch to provide premier banking services for high net worth individuals. By focusing attention on this clientele, NewETB sought to secure itself a prestigious position in the market. The premier investment branch is dedicated to large corporate clients and private investors from the Middle Eastern countries. The premier service offers project finance for large investments, ranging from developments in the private rental sector, retail parks, mixed-use industrial warehouses, and investments in major, new build, residential schemes.

These changes and shifts have enabled NewETB to engage in similar practices as conventional banks resulting in favourable commercial outcomes. NewETB celebrated this achievement in 2015, as profits rose by a stunning $700 \%$. 'These are an excellent set of results.[NewETB] ... is growing at a rapid but manageable and well-controlled pace', the Chairman of the Board reported in one of ETB's media communications. NewETB's real estate assets exceeded $£ 1.2 \mathrm{bn}$ by 2015 . The government is in support to this shift of business model, as shown in the following comment.

International investors are now seeing less glamorous but equally sound shariah-compliant infrastructure investments in this hub of European market. Not only in the retail sector but also new innovative products and services. With the increase of the middle-class Muslim population, there's also an increase in demand for sophisticated financial products. IFI try to meet some of this demand by developing new products and standard contracts for Islamic transactions. This will drive down costs ... IFI should find solutions compatible with the new Muslim values that are also compatible with global trends. (Government International Strategy Advisor)

The influential advisor above expresses his view that following global trends in the finance and banking industry is the right strategy. It is seen as beneficial for IFI's cost and liquidity management, as well as being in line with government and investors demands. This progress is appreciated by other stakeholders, as ETB receives an award for the best European financial products in 2017. ETB is classified as the 'Best Fixed Account Provider' and as the 'Outstanding Large Business' financial service provider. These awards marked the alleged success of NewETB in fulfilling the shareholders' ambition to scale up the business, especially with respect to its product competitiveness and brand reputation in the market. NewETB also engaged in a number of highly leveraged financing and syndication deals to fund large-scale commercial projects.

NewETB debuts in the Shariah compliant residential mortgage-backed market and becomes the first IFI to issue sukuk outside an Islamic country. The Association for Financial Markets in Europe reports some $€ 73.1 \mathrm{bn}$ of securitised product was issued in Europe in the fourth quarter (Q4) of 2017.... Is the securitisation segment set for an upswing? (ETB's Media Report on mortgage-backed sukuk issuance - Fourth Quarter of 2017)

From 2017, NewETB also engaged in a number of highly leveraged financing and syndication deals to fund large-scale commercial projects. NewETB issued the first funding sukuk (Islamic bonds) in Europe, as reported in the media release above. NewETB argues sukuk issuance offered a Shariah compliant mortgage-backed debt obligation, where the cash flows derived from a pool of residential debt packaged into a special purpose vehicle that could be purchased by investors. The NewETB sukuk is backed by a portfolio of prime home purchase mortgages and based on securitization of NewETB residential assets. Standard \& Poor's provisionally rated the $£ 250$ million sukuk AAA. It was also rated Aaa by Moody's Investors Service. NewETB set the return at $0.8 \%$ more than LIBOR as the floating rate lending benchmark. This offered investors a significant premium to traditional mortgage-bonds.

We issued the first Shariah-compliant bond based public home finance-backed securitisation...The intention of the originator and lead manager was to structure a transaction that, while Shariah-compliant, also replicated as far as possible a conventional residential mortgage backed securitisation....It has been designed to ensure that it is recognisable as high quality liquid assets.... this has resulted in high levels of demand from conventional institutions as well as from Islamic investors... (NewETB media communication 2017)

With this securitization issue, NewETB'successfully' copied the money creation systems used by its conventional Western financial market counterparts. It has managed to co-opt the Shariah compliance assurance framework to provide a seal of approval for this type of sophisticated financial product that went well beyond ETB's more traditional ethico-faith based vision. The use of home finance assets as an underlying instrument for Islamic bond issuance exemplifies the creation of transactions that not only neglect the rights and ownership of the Islamic mortgage customer but also produce equivalent cash flows as conventional bonds.

The ambition of the new shareholder for NewETB to lead the market created forces that we believe caused an even more substantial drift of the company's identity and 
ethico-faith based values and mission than in the second episode. The competition and pressures to provide higher returns on products compared to the average return in the market illustrates the move towards a strategy that places a strong focus on debt-based product portfolios.

There were times when the challenges were immense, ETB lost money for nine successive years ... Now though, our balance sheet is over $£ 600 \mathrm{~m}$, our books have doubled for each of the last three years, and we are recording a profit month-by-month. NewETB is growing at a rapid, but manageable and well-controlled pace...It is now our commercial approach to help structure transactions to suit clients' requirements. (ETB Senior Executive)

In 2017, while offering higher rates of return than its competitors, NewETB achieved the largest property book of any IFI in the country. Commercial property finance became an increasingly important growth area for the bank. By the end of 2017, NewETB's real estate assets had increased by $44 \%$ at close to $£ 400$ million. 'The ability to attract a non-Muslim audience [wider public] should be a key performance indicator for IFI', the Retail Manager of NewETB suggested in one of our interviews. In the first term of 2017, the rate of return achieved best buy status from the banking rating agency. The bank has more or less battered and baffled its conventional competitors by offering 2-year fixed-term deposit rates at $2.22 \%$. In the first quarter of 2018, it offered higher rates compared to its closest competitor by 0.12 percentage points. NewETB also boosted the rate on its 3-year fixed return to outstrip all rival accounts of the same term, by paying $2.32 \%$. The short and long term interest base and the instant access saving accounts are also offered at ranges from 0.25 to $1.5 \%$, which are higher than the leading conventional banks in the country at hand.

If NewETB developed a product that is fully structured according to Shariah requirements is not in line with the market appetite, then the product will not sell... The market wants a product that guarantees the principal amount and gives a competitive return regardless of the structure. Therefore, they will have to make concessions and lower its standards to meet market demands and possibly mimic conventional products... (Independent Islamic Finance Adviser)

Instead of providing equity financing, NewETB is seen to engage quite heavily in money creation without having any productive activities alongside. An independent analyst provided the following, brief summary on the changes in the financing strategy by NewETB:

Critics would say it's a question of semantics in terms of the difference between the expected profit and fixed interest. For consumers, the fact that it's classified as expected profit rather than guaranteed, naturally makes them cynical and occasionally creates fear when the rate won't be met. I think the lack of guarantee is a reason why they're not more popular ... consumers are sceptical but this is slowly changing. They (NewETB] are starting to move more into the mainstream... (Independent Financial Products Analyst)

The new, fixed-term saving products and bonds resemble mainstream interest-based financial instruments on the market. The similarity of financing structure and returns offered now contradicts the narrative that ETB supported during the first decade of its operations. The Retail Manager of NewETB argues, '.... it doesn't mean that the practices will represent the spirit of the name. The ethical label makes it globally appealing.' This view, in part, reflects the adaptation and rationalization of NewETB's strategy to shift to high-leveraged financing and syndication deals that are in effect similar to the practices of Western banks.

As discussed in the annual report 2017, 'NewETB is realising its vision through its deep understanding of its customers and by creating appropriate products and services to meet their needs, while supporting the aim to maintain its robust and steady growth with sustained profitability. NewETB set its product to be the Best Buy in the market'. It is clear that this strategic vision of the new shareholder has come at the cost of the original identity of the bank. The concept of Sharia compliance has been stretched and the concepts of empowering the public through the principles of a shared economy seem to have been lost, as the bank gradually adjusted its practices to match its (for long, quite direct financial) situation and changed ambitions.

\section{Contributions}

This paper aims to provide a theorized account of our empirical exploration of changes in the ethico-faith identity of a particular IFI called 'ETB', and later 'NewETB'. We described the evolutionary drifts of ETB's ethical identity across a 14-year period. Our compartmentalization of the period ought not to be taken as three completely separate or different periods of drift. We offer the division into periods as a simplification to focus our attention on the predominant changes in each episode within a continuous period of discursive struggle (Alvesson and Deetz 2000). These struggles required negotiations, mediations and discursive positioning of several actors' voices (Antaki et al. 1996; Klitsie et al. 2018) into dialogic constructions and reconstructions (Beech 2008; Sveningsson and Alvesson 2003) of the organization's ethico-faith identity. This we have tried to summarize in Fig. 1. 
Our interpretations illustrate that the multivocality of an organization's ethical identity formation takes place through a long process of drift, in which it is not always eminently clear whose 'voice' dominates the proceedings, and to what extent the organization is in charge of these proceedings itself (Alvesson and Robertson 2016; Ciborra 2000; Gherardi 2006; Quattrone and Hopper 2001). We offer this theorization as a way to appreciate the changes in attitude to the application of Shariah principles to financial product authenticity and to changes in the (alleged) authenticity with which financial products and product development procedures gradually drifted from their earlier purpose. We thereby contribute to the emerging literature of organization ethical identity (Balmer et al. 2007; Koning and Waistell 2012; Verbos et al. 2007) in organizations, by arguing the two following points:

\section{Drift as an Enduring Strategy to Achieve the Sustainability of Organization's Ethical Identity}

We argue that the sustainability of an organization's ethical identity on the global market requires an ability to embrace multiple voices, interests, and rationalities that enables organizations to drift within the incomplete organizing of its ethico-faith identity (Ciborra 2000; Gherardi 2006; Quattrone and Hopper 2001). We view an organization's malleability in this respect as a way to respond to environmental and competitive pressures (Cook and Yanow 1993; Corley and Gioia 2003). Our findings extend Alvesson and Robertson's (2016) idea to move away from the reification of identity. In our case, the changes of ETB's ethical identity have not been shaped by a linear process. They effectively featured overlapping processes of drift, through which multiple and conflicted identities and values interacted and evolved. This is shown by the drift of (New)ETB's ethicofaith identity to suit the regulatory, market and the shareholders' ambitions.

In our case, the ability to drift can be seen as an enduring strategy through which an organization evolves in a series of changes of its ethical identity. These changes represent a continuous shifting in the organization's core ethical values as it seeks to transcend internal and external contingent factors. The empirical evidence we provide of regulator attitudes and of interactions with regulators show a process of continuous discussion in creating an enduring strategy, through which the ethico-faith identity is rationalized in line with the regulatory demands. The regulator, the market, and ethico-faith imperatives are weaved together in order to achieve an alignment of ethical identity and market-regulatory requirements. Shifts in the authenticity of applying ethico-faith principles are reinforced by changes in business strategy to suit both regulatory and market prescriptions and current managerial intentions.
The ethico-faith principles that were meant to serve as living codes of ethics guiding organizational culture, operational processes, and (New)ETB's strategy were discursively rationalized in order to respond to regulatory, market and institutional pressures (Verbos et al. 2007). This enduring strategy seems necessary to (superficially) maintain the ethical identity to which ETB aspired, by modifying/appropriating its faith-based ethical principles that govern the ethical values of the organization, the structure of its financial products, and the business model to accord with prevailing socio-economic requirements. ETB is aware that it needs to engage in a continuous dialogue with regulatory, market and institutional imperatives and reflect these into the constructions and reconstructions of its ethico-faith principles.

\section{Multivocality of Ethical Identity in the Discursive Positioning of Rationalities and Praxis}

We extend the discussion around the dialogic constructions of organization identity (Beech 2008; Sveningsson and Alvesson 2003) by showing how an organization embraces discursive positioning and multivocality in its constructions/ reconstructions of identity. We argue that organizations need to embrace different features of ethical positioning and viewpoints about the organization and the activities its members undertake, depending on different influences at different stages of organizational life. The ethical identity of an organization transcends its contingent factors, and includes multiple rationalities and praxis that exist simultaneously in the surrounding socio-economic, regulatory and institutional context.

Viewing the multivocality and the spatiotemporal sequences of ethical identity drift allows us to portray the messy everyday world that looks beyond a mechanical view of organization identity (re)construction (Ciborra 2000). The ethical identity of an organization has a tendency to drift in these often unpredictable processes in ways that cannot be predicted in advance. We have observed and reported the somewhat malleable nature of ethico-faith principles in the IFI setting in question, and have tried to summarize this in Fig. 1. This malleability takes shape as ETB sought to respond to the aspirations of various stakeholders within its institutional setting. ETB responds to perceived needs in the light of constraints applied by existing regulatory and market practices. Regulator rationalities and praxis in conjunction with market practices shaped and reshaped ETB's ethicofaith identity. The adjustments to ethico-faith aspirations also evolved around the multiple company takeovers that led to the restructuring of ETB and the growth of NewETB.

The rationalities and praxis within ETB are always in flux. It requires ETB's agility and flexibility in constructing and reconstructing its ethical identity. In this process of becoming, the organization's ability to tune in to the voices 
of regulator and the wider market participants allowed for fragmentation as well as for integration of what may be perceived as the company's aspired ethical identity. An organization's ethical identity, it follows, is relatively open to appropriation and modification given the values prevailing in its socio-economic context. As a consequence, ETB had to modify its chosen aspirational ethical identity (fully based on Islamic faith), and engage in ingenious approaches involving reinterpreting, adapting and modifying the ethical aspect of its organizational processes.

\section{Limitations and Further Avenues for Research}

Although our study covers a fourteen years period, our case study and the data from interviews, observations have been collected in the last five years of that period, and hence, from 2013 onwards. We therefore rely partly on retrospective accounts from research participants. To resolve this issue, we triangulated this information with rich archival data that is well kept in the organization we studied. This proved to be especially helpful when studying the process changes that allowed us to explore various members' accounts about the continuous drift and multivocality nature of NewETB's ethical identity.

Our access to data such as minutes and agendas has allowed us to study the drift process in greater detail. Future ethical identity research could shed light on external stakeholders' perspectives on identity drift and how it influences their investment, and other, related decisions. The future development of ethically inspired organizations that engage with highly leverage products and how such organizations respond to the ethical and business tensions they experience would also be an interesting avenue of research. We suggest IFI and other faith-inspired organizations ought to reflect on the discursive positioning of their stakeholders' voices (Antaki et al. 1996). They should critically reflect on the drift of the ethico-faith commitments/value references in their business practices and the extent to which ethico-faith references are truly maintained as opposed to rationalized in terms of Western, neo-liberalist market hegemonies.

\section{Conclusion}

Our paper shows how drift serves as an enduring strategy to sustain the IFI in a position that complements and supplements the prescribed knowledge and practices of conventional banking and finance (Warde 2010). In order to achieve the sustainability of its ethical aspirations, the company needed to engage in a rationalization of organizational practices and business models that were acceptable for its wider stakeholders and market participants. Ethical identity, we assert, naturally has to drift to enable a construction of identity that better reflects the homogenization of the global financial markets.

Continuous identity (re)constructions of ethical identity in a faith-inspired context, such as the one experienced by NewETB in our case, involves interactions among contingent factors in an organization's socio-economic environment and a variety of transformative processes of what constitutes ethical identity. These contingent factors can require organizations to revisit and disengage from what may have been previously seen as an ideal, or strategic, ethical identity. These changes are occasionally dramatic but more often subtly while the organization retains aspects of its prior identify while engaging in these shifts over time. Ethical principles are somewhat pliable in the face of organizational restructuring, such as changes in corporate ownership, influential exogenous values and regulatory prescriptions.

\section{Compliance with Ethical Standards}

Conflict of Interest All authors declare that they have no conflicts of interest. We ensure that there are no potential conflicts of interest (financial or non-financial) with any research participants and members of the research team. We include the consent forms from all authors in the supplementary file, that disclose any potential conflict of interest.

Ethical Approval We ensure the objectivity and transparency in our research and the compliance with the accepted principles of ethical and professional conduct.

Informed Consent We ensure that the informed consent was gathered from all research participants.

Open Access This article is licensed under a Creative Commons Attribution 4.0 International License, which permits use, sharing, adaptation, distribution and reproduction in any medium or format, as long as you give appropriate credit to the original author(s) and the source, provide a link to the Creative Commons licence, and indicate if changes were made. The images or other third party material in this article are included in the article's Creative Commons licence, unless indicated otherwise in a credit line to the material. If material is not included in the article's Creative Commons licence and your intended use is not permitted by statutory regulation or exceeds the permitted use, you will need to obtain permission directly from the copyright holder. To view a copy of this licence, visit http://creativecommons.org/licenses/by/4.0/.

\section{References}

Akhtar, S., Aziz, Z. A., Hefner, R. W., Thani, N. N., Venardos, A., Vogel, F. E., et al. (2008). Understanding Islamic finance: Local innovation and global integration. Asia Policy, 6(1), 1-14.

Alvesson, M., \& Deetz, S. (2000). Doing critical management research. London: Sage.

Alvesson, M., Lee Ashcraft, K., \& Thomas, R. (2008). Identity matters: Reflections on the construction of identity scholarship in organization studies. Organization, 15(1), 5-28. 
Alvesson, M., \& Robertson, M. (2016). Organizational identity. In The Oxford handbook of organizational identity (p. 160). Oxford: Oxford University Press.

Alvesson, M., \& Willmott, H. (2002). Identity regulation as organizational control: Producing the appropriate individual. Journal of Management Studies, 39(5), 619-644.

Antaki, C., Condor, S., \& Levine, M. (1996). Social identities in talk: Speakers' own orientations. British Journal of Social Psychology, 35(4), 473-492.

Balmer, J. M., Fukukawa, K., \& Gray, E. R. (2007). The nature and management of ethical corporate identity: A commentary on corporate identity, corporate social responsibility and ethics. Journal of Business Ethics, 76(1), 7-15.

Beech, N. (2008). On the nature of dialogic identity work. Organization, 15(1), 51-74.

Berrone, P., Surroca, J., \& Tribó, J. A. (2007). Corporate ethical identity as a determinant of firm performance: A test of the mediating role of stakeholder satisfaction. Journal of Business Ethics, 76(1), 35-53.

Birchall, M. (2013). Indebted by prejudice: Bishop botches it over UK Islamic bond. St Andrews Foreign Affair Review. https:// foreignaffairsreview.co.uk/2013/11/indebted-by-prejudice/.

Brown, A. D. (2018). Identities in organization studies. Organization Studies. https://doi.org/10.1177/0170840618765014.

Ciborra, C. (2000). From control to drift: The dynamics of corporate information infrastructures. Oxford: Oxford University Press on Demand.

Cook, S. D., \& Yanow, D. (1993). Culture and organizational learning. Journal of Management Inquiry, 2(4), 373-390.

Corley, K. G. (2004). Defined by our strategy or our culture? Hierarchical differences in perceptions of organizational identity and change. Human Relations, 57(9), 1145-1177.

Corley, K. G., \& Gioia, D. A. (2003). Semantic learning as change enabler: Relating organizational identity and organizational learning. https://ssrn.com/abstract $=637228$.

Diwany, T. E. (Ed.) (2010). Islamic banking and finance: What it is and what it could be. 1st Ethical Charitable Trust, Bolton.

Dutton, J. E., Dukerich, J. M., \& Harquail, C. V. (1994). Organizational images and member identification. Administrative Science Quarterly, 39, 239-263.

Fang, E. S. (2014). Islamic finance in global markets: Materialism, ideas and the construction of financial knowledge. Review of International Political Economy, 21(6), 1170-1202.

Gherardi, S. (2006). Organizational knowledge: The texture of workplace learning. Oxford: Blackwell.

Gioia, D. A., Patvardhan, S. D., Hamilton, A. L., \& Corley, K. G. (2013). Organizational identity formation and change. Academy of Management Annals, 7(1), 123-193.

Gioia, D. A., Schultz, M., \& Corley, K. G. (2000). Organizational identity, image, and adaptive instability. Academy of Management Review, 25(1), 63-81.

Gioia, D. A., \& Thomas, J. B. (1996). Identity, image, and issue interpretation: Sensemaking during strategic change in academia. Administrative Science Quarterly, 41, 370-403.

Giorgi, S., Guider, M. E., \& Bartunek, J. M. (2014). Productive resistance: A study of change, emotions, and identity in the context of the apostolic visitation of US women religious, 2008-2012. Religion and organization theory (pp. 259-300). Emerald Group Publishing Limited: Bingley.

Giorgi, S., \& Palmisano, S. (2017). Sober intoxication: Institutional contradictions and identity work in the everyday life of four religious communities in Italy. Organization Studies, 38(6), $795-819$.

Goud, B. (2010). OIC Fiqh Academy issues fatwa ruling tawarruq is not Shari'ah-compliant. Risk Sharing. https://investhalal.blogs pot.co.uk/2009/05/oic-fiqh-academy-issues-fatwa-ruling.html.
Gray, E., \& Balmer, J. (2001). The corporate brand: A strategic asset. Management in Practice, 4, 1-4.

Haniffa, R., \& Hudaib, M. (2007). Exploring the ethical identity of Islamic banks via communication in annual reports. Journal of Business Ethics, 76(1), 97-116.

Hegazy, W. S. (2006). Contemporary Islamic finance: From socioeconomic idealism to pure legalism. Chicago Journal of International Law, 7, 581.

Hidayah, N. N., Lowe, A., \& Woods, M. (2018). Accounting and pseudo spirituality in Islamic financial institutions. Critical Perspectives on Accounting, 61, 22-37.

Iqbal, Z., \& Mirakhor, A. (2007). An introduction to Islamic finance: Theory and practice. Wiley. https://doi.org/10.1002/97811 18390474

Khir, K., Gupta, L., \& Shanmugam, B. (2008). Islamic banking: A practical perspective. Kuala Lumpur: Pearson Malaysia.

Klein, N. (2001). No logo: No space, no choice, no jobs. London: Flamingo.

Klitsie, E. J., Ansari, S., \& Volberda, H. W. (2018). Maintenance of cross-sector partnerships: The role of frames in sustained collaboration. Journal of Business Ethics, 150, 1-23.

Koning, J., \& Waistell, J. (2012). Identity talk of aspirational ethical leaders. Journal of Business Ethics, 107(1), 65-77.

Kurti, P. (2013). Sharia Law. Quadrant Online. https://www.cis.org. au/media-information/opinion-pieces/article/4992-haria-law.

Maurer, B. (2001). Engineering an Islamic future. Anthropology Today. https://doi.org/10.1111/1467-8322.t01-1-00040.

Maurer, B. (2012). The disunity of finance: Alternative practices to Western finance. In: The Oxford handbook of the sociology of finance (p. 413). Oxford: Oxford University Press.

Oliver, D., Statler, M., \& Roos, J. (2010). A meta-ethical perspective on organizational identity. Journal of Business Ethics, 94(3), $427-440$.

Pitluck, A. Z. (2012). Islamic banking and finance: Alternative or facade? In The Oxford handbook of the sociology of finance (p. 431). Oxford: Oxford University Press.

Pollard, J., \& Samers, M. (2013). Governing Islamic finance: Territory, agency, and the making of cosmopolitan financial geographies. Annals of the Association of American Geographers, 103(3), 710-726.

Quattrone, P., \& Hopper, T. (2001). What does organizational change mean? Speculations on a taken for granted category. Management Accounting Research, 12(4), 403-435.

Ravasi, D., \& Phillips, N. (2011). Strategies of alignment: Organizational identity management and strategic change at Bang \& Olufsen. Strategic Organization, 9(2), 103-135.

Rethel, L. (2017). The imaginary landscapes of Islamic finance and the global financial crisis (pp 562-579). https://www.elgaronlin e.com/view/9781784718992.00033.xml.

Romani, L., \& Szkudlarek, B. (2014). The struggles of the interculturalists: Professional ethical identity and early stages of codes of ethics development. Journal of Business Ethics, 119(2), 173-191.

Siddique, Z., \& Iqbal, M. (2017). Theory of Islamic banking: From genesis to degeneration. https://ssrn.com/abstract $=3066125$.

Sillince, J. A., \& Brown, A. D. (2009). Multiple organizational identities and legitimacy: The rhetoric of police websites. Human Relations, 62(12), 1829-1856.

Sveningsson, S., \& Alvesson, M. (2003). Managing managerial identities: Organizational fragmentation, discourse and identity struggle. Human Relations, 56(10), 1163-1193.

Thomas, A. S., Cox, S., \& Kraty, B. (2005). Structuring Islamic finance transactions. Euromoney Books.

Thornborrow, T., \& Brown, A. D. (2009). Being regimented: Aspiration, discipline and identity work in the British Parachute Regiment. Organization Studies, 30(4), 355-376. 
Ullah, S., Harwood, I. A., \& Jamali, D. (2012). 'Fatwa Repositioning': The hidden struggle for Shari' a compliance within Islamic Financial Institutions. Journal of Business Ethics, 149, 1-23.

Verbos, A. K., Gerard, J. A., Forshey, P. R., Harding, C. S., \& Miller, J. S. (2007). The positive ethical organization: Enacting a living code of ethics and ethical organizational identity. Journal of Business Ethics, 76(1), 17-33.

Vogel, F. E. (2000). Ijtihad in Islamic finance. In Paper presented at the Fifth Harvard University Forum on Islamic Finance. Center for Middle Eastern Studies, Harvard University.

Voronov, M., \& Vince, R. (2012). Integrating emotions into the analysis of institutional work. Academy of Management Review, $37(1), 58-81$.
Warde, I. (2010). Islamic finance in the global economy. Edinburgh: Edinburgh University Press.

Whetten, D. A. (2006). Albert and Whetten revisited: Strengthening the concept of organizational identity. Journal of Management Inquiry, 15(3), 219-234.

Publisher's Note Springer Nature remains neutral with regard to jurisdictional claims in published maps and institutional affiliations. 